\title{
The mitochondrial genome of Brachycephalus brunneus (Anura: Brachycephalidae), with comments on the phylogenetic position of Brachycephalidae
}

\author{
Marcio R. Pie a, b, *, Patrícia R. Ströher a, Marcos R. Bornschein ${ }^{b, c}$, \\ Luiz F. Ribeiro $^{\text {b, d }}$, Brant C. Faircloth ${ }^{\mathrm{e}}$, John E. McCormack ${ }^{\mathrm{f}}$ \\ a Departamento de Zoologia, Universidade Federal do Paraná, CEP 81531-990, Curitiba, Paraná, Brazil \\ ${ }^{\mathrm{b}}$ Mater Natura - Instituto de Estudos Ambientais, CEP 80250-020, Curitiba, Paraná, Brazil \\ ${ }^{\mathrm{c}}$ Instituto de Biociências, Universidade Estadual Paulista, Praça Infante Dom Henrique s/no, Parque Bitaru, CEP 11330-900, São Vicente, \\ São Paulo, Brazil \\ d Escola de Saúde, Pontifícia Universidade Católica do Paraná, CEP 80215-901, Curitiba, Paraná, Brazil \\ e Department of Biological Sciences and Museum of Natural Science, Louisiana State University, Baton Rouge, LA 70803, USA \\ ${ }^{\mathrm{f}}$ Moore Laboratory of Zoology, Occidental College, 1600 Campus Road, Los Angeles, CA 90041, USA
}

\section{A R T I C L E I N F O}

\section{Article history:}

Received 28 October 2016

Received in revised form 16 December 2016

Accepted 18 December 2016

Available online 26 January 2017

\section{Keywords:}

Anuran

Brazil

Terrarana

Atlantic forest

\begin{abstract}
A B S T R A C T
The mitochondrial genome of Brachycephalus brunneus was determined by nextgeneration sequencing of mitochondrial DNA. Without its control region, it has a total length of 15,485 bp, consisting of 37 genes: 13 protein-coding genes, 2 rRNA genes, and 22 tRNA genes. Except for eight tRNAs and the nd6 gene, all other mitochondrial genes are encoded on the heavy strand. ATG and ATC act mainly as the initial codon in 10 proteincoding genes, whereas nd2 and cox 1 use ATT and nad3 uses ATA. Gene order is generally consistent with that observed in closely-related families. The cloverleaf structures for trnS1 and trnC lacked the DHU-stem and DHU-loop, respectively. Phylogenetic analyses of mitogenomes of closely-related families indicate that Brachycephalidae is more closelyrelated to Craugastoridae than to Eleutherodactylidae. This is the first sequenced mitochondrial genome for the entire Brachycephalidae and can provide the basis for the development of mitochondrial markers for other members of the family, including many species that are critically endangered.
\end{abstract}

() 2017 Elsevier Ltd. All rights reserved.

\section{Introduction}

Brachycephalidae is an intriguing family of Neotropical anurans. The first brachycephalid species was described by Spix in 1824 within Bufo ephippium, but soon afterwards was established as a monotypic genus by Fitzinger (1826). Brachycephalus was believed to be most closely related to Atelopus based on similarities in its pectoral girdle similarities (Griffiths, 1959). Later, McDiarmid (1971) placed Brachycephalus in its own family based mostly on the lack of a Bidder's organ, which could indicate phylogenetic proximity to Bufonidae. However, following extensive phylogenetic analyses and taxonomic reassignments (e.g. Frost et al., 2006; Hedges et al., 2008), the modern composition of Brachycephalidae now includes

\footnotetext{
* Corresponding author. Departamento de Zoologia, Universidade Federal do Paraná, Caixa Postal 19020, CEP 81531-980, Curitiba, Paraná, Brazil.

E-mail address: marcio.pie@gmail.com (M.R. Pie).
} 
Brachycephalus and Ischnocnema (Hedges et al., 2008). Brachycephalus is composed of 30 currently recognized species (Frost, 2016), and includes miniaturized, highly endemic frog species distributed mostly in montane forests of the Atlantic Forest of south and southeastern Brazil (Pie et al., 2013; Bornschein et al., 2016), whereas Ischnocnema is currently composed of 33 species and has a broader geographical distribution throughout central and southern Brazil, northern Argentina, and possibly into adjacent Paraguay (Frost, 2016).

Recent studies have placed Brachycephalidae as closely related to two hyloid families, namely Craugastoridae and Eleutherodactylidae, but the relationships among these three families is still uncertain. For instance, although some studies place Brachycephalidae as more closely related to Craugastoridae (Darst and Cannatella, 2004; Frost et al., 2006), another study suggested that Craugastoridae is more closely related to Eleutherodactylidae than to Brachycephalidae (Pyron and Wiens, 2011). In this study, we determined the mitochondrial genome of Brachycephalus brunneus using next generation sequencing, the first brachycephalid mitogenome to date, and use it to assess the phylogenetic position of Brachycephalidae.

\section{Materials and methods}

\subsection{Specimen}

An adult of Brachycephalus brunneus was collected in the type locality of the species: Caratuva $\left(25^{\circ} 14^{\prime} 33^{\prime \prime} \mathrm{S}, 48^{\circ} 50^{\prime} 04^{\prime \prime} \mathrm{W}\right)$, municipality of Campina Grande do Sul, state of Paraná, southern Brazil. Tissue samples were preserved in absolute ethanol and kept in $-20^{\circ} \mathrm{C}$ freezer until use. The corresponding specimen was deposited in the Museu de História Natural Capão da Imbuia (MHNCI), Curitiba, state of Paraná.

\subsection{DNA extraction and library preparation}

Total genomic DNA was extracted using PureLink ${ }^{\mathrm{TM}}$ Genomic DNA kit (Invitrogen ${ }^{\mathrm{TM}}$, USA), according to the manufacturer's instructions. The purified genomic DNA was quantified using the Qubit dsDNA HS assay Kit (Life Technologies, USA). mtDNA sequences of B. brunneus were obtained as off-target regions from another study (Pie et al., unpublished results) using target capture of ultraconserved elements (UCEs; see Faircloth et al., 2012).

\subsection{Sequence and genome analysis}

We assembled reads into the mtDNA sequence using Trinity (Grabherr et al., 2011), as implemented in PHYLUCE (Faircloth, 2015), which is part of the UCE-processing pipeline. As expected (Hung et al., 2013), the longest contig included the entire mtDNA genome except for the control region. Annotation was carried out using MITOS (Bernt et al., 2013). The sequin file generated from MITOS was submitted to NCBI (accession number KY355081).

\subsection{Phylogenetic analysis}

Mitogenomes of Eleutherodactylus atkinsi and Craugastor augusti were used as representatives of Eleutherodactylidae and Craugastoridae, respectively. These are the only mitogenomes of those families currently available on GenBank. As outgroups, we selected mitogenomes of four closely-related families, namely Centrolenidae, Leptodactylidae, Dendrobatidae, Bufonidae and Odontophrynidae (Table 1). Sequences for each gene were separately aligned using MUSCLE 3.8.31 (Edgar, 2004), although the relatively low number of indels would probably lead to nearly identical alignments using other programs. Analyses included all protein-coding, ribosomal and tRNA genes except $t R N A_{p h e}$, $t R N A_{\text {thr }}$ and $t R N A_{p r o}$, which were not included given that they are often not available from other frog genomes. Model selection and partitioning using PartitionFinder 1.1.0 (Lanfear et al., 2012) based on the Bayesian information criterion and the greedy search scheme. Phylogenetic analysis using Bayesian Inference (BI) was conducted using MrBayes 3.2 (Ronquist et al., 2012) with $2 \times 10^{6}$ MCMC generations with four chains and sampling every $200^{\text {th }}$ generation, with the first $25 \%$ of the chains being discarded as burnin. Maximum likelihood (ML) analyses using the same partitioning scheme were carried out using RAxML (Stamatakis et al., 2008, as implemented in http://embnet.vital-it.ch/raxml-bb/), with branch support obtained using 500 pseudoreplicates.

Table 1

Species used in phylogenetic analyses in the present study.

\begin{tabular}{lll}
\hline Species & Family & Accession Number \\
\hline Anomaloglossus baeobatrachus & Dendrobatidae & NC_030054 \\
Brachycephalus brunneus & Brachycephalidae & KY355081 \\
Bufo tibetanus & Bufonidae & NC_020048 \\
Craugastor augusti & Craugastoridae & JX564870 \\
Eleutherodactylus atkinsi & Eleutherodactylidae & JX564864 \\
Hyalinobatrachium fleischmanni & Centrolenidae & JX564869 \\
Leptodactylus melanonotus & Leptodactylidae & JX564873 \\
Odontophrynus occidentalis & Odontophrynidae & JX564880 \\
\hline
\end{tabular}




\section{Results}

\subsection{Mitogenome analysis and features}

The total length of the Brachycephalus brunneus mitochondrial genome sequence is 15,485 bp. It consists of 13 proteincoding genes, 2 rRNA genes ( $r r n S$ and $r r n L), 22$ tRNA genes (the control region was not sequenced; Table 2). ATG and ATC act mainly as the initial codon in 10 protein-coding genes, whereas nd2 and cox1 use ATT and nd3 uses ATA. With the exception of eight tRNAs and nd6 gene, all other mitochondrial genes are encoded on the heavy strand (H strand). Spacing sequences ranged from one to $179 \mathrm{bp}$, with the latter being found between atp 6 and cox3. The rRNAs are located between trnF and $t r n L 2$ genes and are separated by the trnV gene. The putative secondary structure for all tRNA genes of B. brunneus are shown in Fig. 1. As commonly observed in other metazoans, trnS1 and trnC lacked the dihydrouracil (DHU) stem and loop, respectively (Fig. 1). Base composition across all genes was $A=30.0 \%, C=25.5 \%, G 14.8 \%$, and $\mathrm{T} 29.7 \%$, but these values differed considerably between genes. tRNAs varied their GC content from $25.8 \%$ in trnF to over $51 \%$ in trnK and trnY. Proteincoding genes varied less in base composition, from 36\% GC in atp 8 to 42.6 in cox1. Finally, a relatively higher GC content was found in ribosomal genes: 39.4 and 43.6 for $r r n L$ and $r r n S$, respectively.

The total alignment for phylogenetic analysis was $14,927 \mathrm{bp}$. Model selection using PartitionFinder indicated an optimal partitioning scheme with six partitions, with tRNAs being assigned to three different partitions (one of which also including rrnS and rrnL genes), whereas protein-coding genes were assigned to three different partitions (Table 3). BI analysis using this partitioning scheme reached apparent stabilization of MCMC chains, with average standard deviation of split frequencies being lower than 0.0002 and ESS of estimated parameters almost invariably exceeding 300 . The obtained phylogenetic relationships are indicated in Fig. 2. In particular, B. brunneus is more closely related to Graugastor augusti than to Eleutherodactylus atkinsi, with $100 \%$ bootstrap support and posterior probabilities, suggesting that Brachycephalidae is more closelyrelated to Craugastoridae than to Eleutherodactylidae.

Table 2

Characteristics of the mitochondrial genome of Brachycephalus brunneus.

\begin{tabular}{|c|c|c|c|c|c|c|c|c|c|c|c|}
\hline \multirow[t]{2}{*}{ Gene } & \multicolumn{2}{|c|}{ Position } & \multirow[t]{2}{*}{ Length (bp) } & \multirow{2}{*}{$\begin{array}{l}\text { Intergenic } \\
\text { nucleotides }\end{array}$} & \multirow[t]{2}{*}{ Strand } & \multicolumn{6}{|c|}{ Nucleotides } \\
\hline & From & To & & & & A & C & G & $\mathrm{T}$ & $G+C$ & $A+T$ \\
\hline$c o b$ & 1 & 1110 & 1110 & & - & 27.66 & 26.49 & 12.97 & 32.88 & 39.46 & 60.54 \\
\hline $\operatorname{trn} E$ & 1125 & 1192 & 68 & 15 & + & 26.47 & 16.18 & 22.06 & 35.29 & 38.24 & 61.76 \\
\hline$n d 6$ & 1193 & 1698 & 506 & 0 & + & 16.57 & 9.86 & 31.56 & 42.01 & 41.42 & 58.58 \\
\hline nd5 & 1701 & 3467 & 1767 & 3 & - & 30.45 & 28.07 & 11.09 & 30.39 & 39.16 & 60.84 \\
\hline trnS1 & 3516 & 3582 & 67 & 49 & - & 34.33 & 16.42 & 14.93 & 34.33 & 31.34 & 68.66 \\
\hline $\operatorname{trnH}$ & 3583 & 3652 & 70 & 0 & - & 25.71 & 28.57 & 17.14 & 28.57 & 45.71 & 54.29 \\
\hline nd4 & 3658 & 5016 & 1359 & 6 & - & 30.32 & 27.74 & 11.77 & 30.17 & 39.51 & 60.49 \\
\hline$n d 4 l$ & 5013 & 5278 & 266 & -3 & - & 28.46 & 28.84 & 11.61 & 31.09 & 40.45 & 59.55 \\
\hline $\operatorname{trn} R$ & 5310 & 5378 & 69 & 32 & - & 33.33 & 27.54 & 15.94 & 23.19 & 43.48 & 56.52 \\
\hline nd3 & 5380 & 5727 & 348 & 2 & - & 29.31 & 25.57 & 14.94 & 30.17 & 40.52 & 59.48 \\
\hline $\operatorname{trn} G$ & 5719 & 5785 & 67 & -8 & - & 32.84 & 26.87 & 14.93 & 25.37 & 41.79 & 58.21 \\
\hline $\cos 3$ & 5787 & 6569 & 783 & 2 & - & 27.08 & 27.2 & 14.56 & 31.16 & 41.76 & 58.24 \\
\hline atp6 & 6748 & 7419 & 672 & 179 & - & 28.42 & 27.98 & 11.61 & 31.99 & 39.58 & 60.42 \\
\hline atp8 & 7416 & 7571 & 156 & -3 & - & 36.54 & 30.77 & 5.13 & 27.56 & 35.9 & 64.1 \\
\hline $\operatorname{trnK}$ & 7572 & 7641 & 70 & 0 & - & 31.43 & 30 & 21.43 & 17.14 & 51.43 & 48.57 \\
\hline $\operatorname{cox} 2$ & 7649 & 8320 & 672 & 8 & - & 31.99 & 25.3 & 14.43 & 28.27 & 39.73 & 60.27 \\
\hline $\operatorname{trn} D$ & 8344 & 8412 & 69 & 24 & - & 36.23 & 21.74 & 14.49 & 27.54 & 36.23 & 63.77 \\
\hline $\operatorname{trnS2}$ & 8414 & 8484 & 71 & 2 & + & 23.94 & 14.08 & 26.76 & 35.21 & 40.85 & 59.15 \\
\hline $\operatorname{cox} 1$ & 8486 & 10,016 & 1531 & 2 & - & 25.42 & 26.27 & 16.34 & 31.96 & 42.61 & 57.39 \\
\hline $\operatorname{trn} Y$ & 10,024 & 10,090 & 67 & 8 & + & 22.39 & 19.4 & 35.82 & 22.39 & 55.22 & 44.78 \\
\hline $\operatorname{trn} C$ & 10,091 & 10,144 & 54 & 0 & + & 33.33 & 22.22 & 27.78 & 16.67 & 50 & 50 \\
\hline $\operatorname{trnN}$ & 10,172 & 10,244 & 73 & 28 & + & 24.66 & 13.7 & 27.4 & 34.25 & 41.1 & 58.9 \\
\hline $\operatorname{trn} A$ & 10,245 & 10,313 & 69 & 0 & + & 30.43 & 11.59 & 23.19 & 34.78 & 34.78 & 65.22 \\
\hline $\operatorname{trnW}$ & 10,313 & 10,382 & 70 & -1 & - & 36.23 & 26.09 & 14.49 & 23.19 & 40.58 & 59.42 \\
\hline$n d 2$ & 10,396 & 11,415 & 1020 & 14 & - & 33.53 & 27.94 & 9.8 & 28.73 & 37.75 & 62.25 \\
\hline trnM & 11,416 & 11,484 & 69 & 0 & - & 30.43 & 24.64 & 15.94 & 28.99 & 40.58 & 59.42 \\
\hline $\operatorname{trn} Q$ & 11,484 & 11,554 & 71 & -1 & + & 28.17 & 14.08 & 21.13 & 36.62 & 35.21 & 64.79 \\
\hline trnI & 11,554 & 11,623 & 70 & -1 & - & 27.14 & 24.29 & 25.71 & 22.86 & 50 & 50 \\
\hline nd1 & 11,631 & 12,548 & 918 & 8 & - & 28.1 & 28.54 & 12.2 & 31.15 & 40.74 & 59.26 \\
\hline $\operatorname{trnL2}$ & 12,589 & 12,659 & 71 & 41 & - & 33.8 & 16.9 & 15.49 & 33.8 & 32.39 & 67.61 \\
\hline$r r n L$ & 12,655 & 14,185 & 1531 & -4 & - & 35.73 & 22.66 & 16.79 & 22.82 & 39.45 & 60.55 \\
\hline $\operatorname{trnV}$ & 14,186 & 14,255 & 70 & 0 & - & 38.57 & 22.86 & 12.86 & 25.71 & 35.71 & 64.29 \\
\hline$r r n S$ & 14,253 & 15,183 & 931 & -2 & - & 33.4 & 25.56 & 18.05 & 22.99 & 43.61 & 56.39 \\
\hline $\operatorname{trn} F$ & 15,184 & 15,249 & 66 & 0 & - & 45.45 & 13.64 & 12.12 & 28.79 & 25.76 & 74.24 \\
\hline $\operatorname{trn} P$ & 15,249 & 15,317 & 69 & -1 & + & 26.09 & 11.59 & 27.54 & 34.78 & 39.13 & 60.87 \\
\hline $\operatorname{trnT}$ & 15,317 & 15,383 & 67 & -1 & - & 35.82 & 19.4 & 20.9 & 23.88 & 40.3 & 59.7 \\
\hline $\operatorname{trnL1}$ & 15,384 & 15,455 & 72 & 0 & - & 26.39 & 23.61 & 20.83 & 29.17 & 44.44 & 55.56 \\
\hline
\end{tabular}



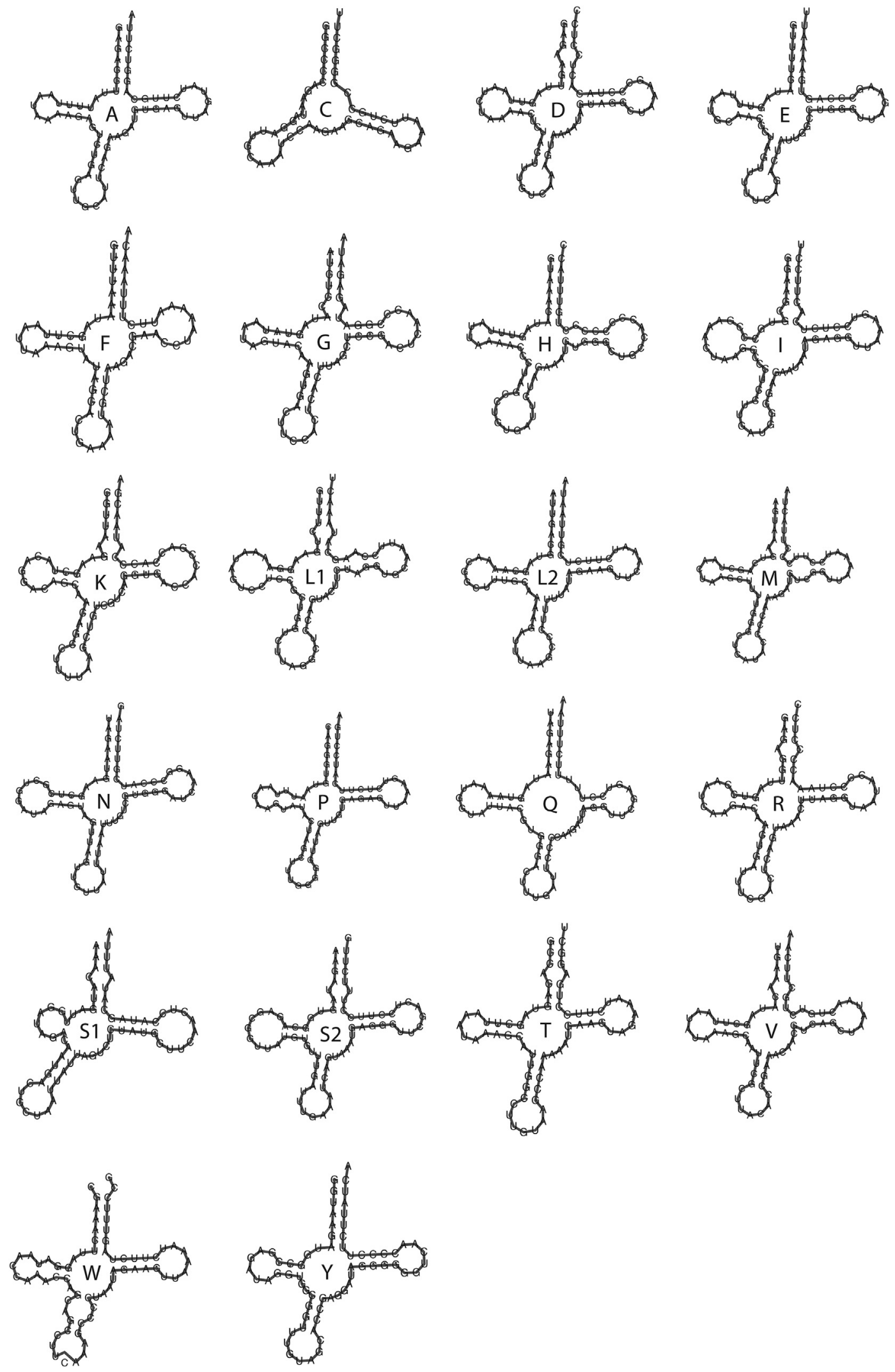

Fig. 1. Cloverleaf structure of the 22 inferred tRNAs in the mitogenome of Brachycephalus brunneus. 
Table 3

Models of evolution for each partition of the studied alignment.

\begin{tabular}{|c|c|c|}
\hline Partition & Best Model & Genes \\
\hline 1 & $\mathrm{GTR}+\Gamma$ & rrnS, rrnS, trnI, trnW, trnN, trnS2, trnK \\
\hline 2 & $\mathrm{HKY}+\Gamma$ & $\operatorname{trn} V, \operatorname{trn} L 2, \operatorname{trn} Q, \operatorname{trn} A, \operatorname{trn} D, \operatorname{trn} G, \operatorname{trn} R, \operatorname{trn} H, \operatorname{trnS} 1, \operatorname{trn} E$ \\
\hline 3 & $\mathrm{GTR}+\mathrm{I}+\Gamma$ & $n d 1, \operatorname{cox} 1, \operatorname{cox} 2, \operatorname{cox} 3, \operatorname{cob}$ \\
\hline 4 & $\mathrm{~K} 80+\Gamma$ & $\operatorname{trn} M, \operatorname{trn} C, \operatorname{trn} Y$ \\
\hline 5 & $\mathrm{GTR}+\mathrm{I}+\Gamma$ & nd2, atp8, atp6, nd3, nd4L, nd4, nd5 \\
\hline 6 & $\mathrm{HKY}+\Gamma$ & nd6 \\
\hline
\end{tabular}

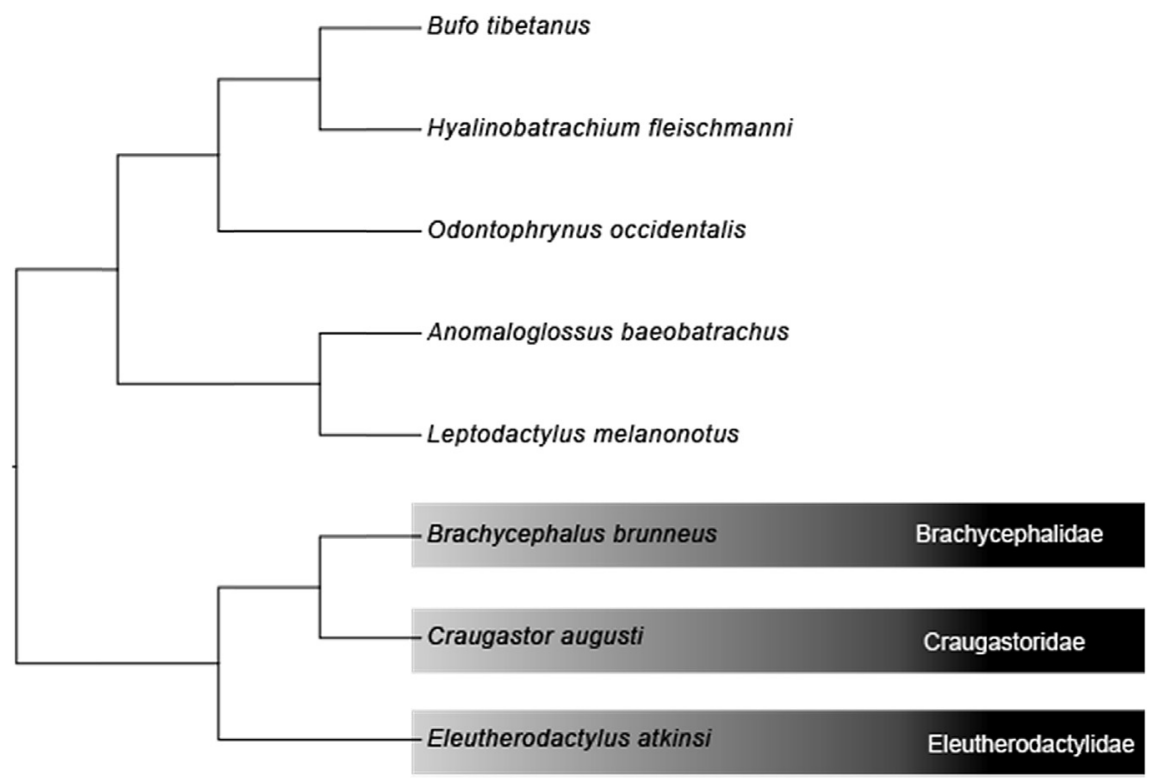

Fig. 2. Phylogenetic relationships between Brachycephalidae, Craugastoridae, and Eleutherodactylidae, as inferred based on Bayesian Inference analysis of mitogenomes of representatives of each family. All nodes received $100 \%$ posterior probabilities. Maximum likelihood analyses provided the same ingroup topology with $100 \%$ bootstrap support.

\section{Discussion}

The overall structure of the mitogenome of Brachycephalus brunneus shared similarities with closely-related neobatrachian lineages, including gene order (e.g. Cao et al., 2006; Wang et al., 2013; Zhang et al., 2013), codon usage (Cao et al., 2006), and low GC content (e.g. Cao et al., 2006; Lloyd et al., 2012). Interestingly, the loss of the DHU-stem and DHU-loop in trnS1 and trnC is also shared with other anurans, such as the ranoid Paa spinosa (Zhou et al., 2009) and the microhylid Microhyla butleri (Yong et al., 2016).

The phylogenetic relationships inferred in the present study indicate that Brachycephalidae is more closely-related to Craugastoridae than to Eleutherodactylidae, contrary to some previous studies based on datasets with fewer genes (Pyron and Wiens, 2011). The agreement between our results and those of Darst and Cannatella (2004) and Frost et al. (2006) is not surprising, given that those studies themselves were based on mitochondrial DNA, particularly the rrnS and $r r n L$ genes. Given the strong phylogenetic signal indicated in our analyses, it seems clear that the mitochondrial tree supports that Brachycephalidae and Craugastoridae are sister taxa. However, more extensive sampling, both of other species and of nuclear loci, are crucial to confirm this finding, particularly to confirm the monophyly of Eleutherodactylidae.

Finally, this study underscores the utility of using off-target sequences from sequence-capture methods, such as UCEs (Amaral et al., 2015). As the use of next-generation sequencing becomes more prevalent, the assembly of mitogenomes can become an inexpensive complementary marker that can be highly informative, not only in terms of sequence data, but also secondary structure and gene order (Zhang et al., 2013). In particular, gene reorganization has been detected many times across Neobatrachia (e.g. Xia et al., 2014) and their relatively low rates of homoplasy might provide valuable markers, particularly for higher-level relationships in Anura. Furthermore, the availability of the mitochondrial genome of Brachycephalus brunneus opens the possibility for the development of mitochondrial markers for other species of the family as well. Such markers can be used in intra and interspecific studies, including many microendemic species that are critically endangered. 


\section{Acknowledgements}

We thank W. Tsai for assistance during laboratory work. Samples were collected under ICMBIO permit \#22470-2 and Instituto Ambiental do Paraná permit 355/11. This study was funded by the Fundação Grupo Boticário de Proteção à Natureza (grants 0895_20111 and A0010_2014), as well as a grant from CNPq to MRP (grant 571334/2008-3).

\section{References}

Amaral, F.R., do Neves, L.G., Resende, M.F.R., Mobili, F., Miyaki, C.Y., Pellegrino, K.C.M., Biondo, C., 2015. Ultraconserved elements sequencing as a low-cost source of complete mitochondrial genomes and microsatellite markers in non-model amniotes. PLoS One 10, e0138446. http://dx.doi.org/10.1371/ journal.pone.0138446.

Bernt, M., Donath, A., Jühling, F., Externbrink, F., Florentz, C., Fritzsch, G., Pütz, J., Middendorf, M., Stadler, P.F., 2013. MITOS: improved de novo metazoan mitochondrial genome annotation. Mol. Phylogenetics Evol. 69, 313-319. http://dx.doi.org/10.1016/j.ympev.2012.08.023.

Bornschein, M.R., Firkowski, C.R., Belmonte-Lopes, R., Corrêa, L., Ribeiro, L.F., Morato, S.A.A., Antoniazzi-Jr., R.L., Reinert, B.L., Meyer, A.L.S., Cini, F.A., Pie, M.R., 2016. Geographical and altitudinal distribution of Brachycephalus (Anura: Brachycephalidae) endemic to the Brazilian Atlantic Rainforest, PeerJ, 4, p. e2490. http://dx.doi.org/10.7717/peerj.2490.

Cao, S.-Y., Wu, X.-B., Yan, P., Hu, Y.-L., Su, X., Jiang, Z.-G., 2006. Complete nucleotide sequences and gene organization of mitochondrial genome of Bufo gargarizans. Mitochondrion 6, 186-193. http://dx.doi.org/10.1016/j.mito.2006.07.003.

Darst, C.R., Cannatella, D.C., 2004. Novel relationships among hyloid frogs inferred from 12S and 16S mitochondrial DNA sequences. Mol. Phylogenet. Evol. $31,462-475$.

Edgar, R.C., 2004. MUSCLE: multiple sequence alignment with high accuracy and high throughput. Nucleic Acids Res. 32, $1792-1797$. http://dx.doi.org/10. $1093 / \mathrm{nar} / \mathrm{gkh} 340$.

Faircloth, B.C., 2015. PHYLUCE is a software package for the analysis of conserved genomic loci. Bioinformatics 32, 786-788. http://dx.doi.org/10.1093/ bioinformatics/btv646.

Faircloth, B.C., McCormack, J.E., Crawford, N.G., Harvey, M.G., Brumfield, R.T., Glenn, T.C., 2012. Ultraconserved elements anchor thousands of genetic markers spanning multiple evolutionary timescales. Syst. Biol. 61, 717-726. http://dx.doi.org/10.1093/sysbio/sys004.

Fitzinger, L.J., 1826. Neue classification der reptilien nach ihren natürlichen verwandtschaften: nebst einer verwandtschafts-tafel und einem verzeichnisse der reptilien-sammlung des K. K. zoologischen museum's zu Wien J. G. Huebner (Wien).

Frost, D.R., 2016. Amphibian species of the world: an online reference. Version 6.0. [WWW Document]. URL. http://research.amnh.org/vz/herpetology/ amphibia/ (accessed 16).

Frost, D.R., Grant, T., Faivovich, J., Bain, R.H., Haas, A., Haddad, C.F.B., de Sa, R.O., Channing, A., Wilkinson, M., Donnellan, S.C., Raxworthy, C.J., Campbell, J.A., Blotto, B.L., Moler, P., Drewes, R.C., Nussbaum, R.A., Lynch, J.D., Green, D.M., Wheeler, W.C., 2006. The Amphibian Tree of Life. Bulletin of the AMNH. no. 297.

Grabherr, M.G., Haas, B.J., Yassour, M., Levin, J.Z., Thompson, D.A., Amit, I., Adiconis, X., Fan, L., Raychowdhury, R., Zeng, Q., Chen, Z., Mauceli, E., Hacohen, N., Gnirke, A., Rhind, N., di Palma, F., Birren, B.W., Nusbaum, C., Lindblad-Toh, K., Friedman, N., Regev, A., 2011. Full-length transcriptome assembly from RNA-Seq data without a reference genome. Nat. Biotechnol. 29, 644-652. http://dx.doi.org/10.1038/nbt.1883.

Griffiths, I., 1959. The phylogeny of Sminthillus limbatus and the status of the Brachycephalidae (Amphibia Salientia). Proc. Zoological Soc. Lond. 132, 457-487. http://dx.doi.org/10.1111/j.1469-7998.1959.tb05531.x.

Hedges, B.S., Duellman, W.E., Heinicke, M.P., 2008. New world direct-developing frogs (Anura: terrarana): molecular phylogeny, classification, biogeography, and conservation. Zootaxa 1737, 1-182.

Hung, C.-M., Lin, R.-C., Chu, J.-H., Yeh, C.-F., Yao, C.-J., Li, S.-H., 2013. The de novo assembly of Mitochondrial Genomes of the extinct passenger pigeon (Ectopistes migratorius) with next generation Sequencing. PLoS ONE 8, e56301. http://dx.doi.org/10.1371/journal.pone.0056301.

Lanfear, R., Calcott, B., Ho, S.Y.W., Guindon, S., 2012. PartitionFinder: combined selection of partitioning schemes and substitution models for phylogenetic analyses. Mol. Biol. Evol. 29, 1695-1701. http://dx.doi.org/10.1093/molbev/mss020.

Lloyd, R.E., Foster, P.G., Guille, M., Littlewood, D.T.J., 2012. Next generation sequencing and comparative analyses of Xenopus mitogenomes. BMC Genomics 13, 496. http://dx.doi.org/10.1186/1471-2164-13-496.

McDiarmid, R.W., 1971. Comparative morphology and evolution of frogs on the Neotropical genera Atelopus, Dendrophryniscus, Melanophryniscus and. Oreophrynella. Sci. Bull. Nat. Hist. Mus. Los Angeles Co. 12, 1-66.

Pie, M.R., Meyer, A.L.S., Firkowski, C.R., Ribeiro, L.F., Bornschein, M.R., 2013. Understanding the mechanisms underlying the distribution of microendemic montane frogs (Brachycephalus spp., Terrarana: Brachycephalidae) in the Brazilian Atlantic Rainforest. Ecol. Model. 250, 165-176. http://dx.doi.org/10. 1016/j.ecolmodel.2012.10.019.

Pyron, A.R., Wiens, J.J., 2011. A large-scale phylogeny of Amphibia including over 2800 species, and a revised classification of extant frogs, salamanders, and caecilians. Mol. Phylogenetics Evol. 61, 543-583. http://dx.doi.org/10.1016/j.ympev.2011.06.012.

Ronquist, F., Teslenko, M., van der Mark, P., Ayres, D.L., Darling, A., Hohna, S., Larget, B., Liu, L., Suchard, M.A., Huelsenbeck, J.P., 2012. MrBayes 3.2: efficient Bayesian Phylogenetic inference and model choice across a large model space. Syst. Biol. 61, 539-542. http://dx.doi.org/10.1093/sysbio/sys029.

Stamatakis, A., Hoover, P., Rougemont, J., 2008. A rapid bootstrap algorithm for the RAxML web-servers. Syst. Biol. 75, 758-771. http://dx.doi.org/10.1080/ 10635150802429642.

Wang, X., Wang, Y., Yue, B., Zhang, X., Liu, S., 2013. The complete mitochondrial genome of the Bufo tibetanus (Anura: Bufonidae). Mitochondrial DNA 24, 186-188. http://dx.doi.org/10.3109/19401736.2012.744978.

Xia, Y., Zheng, Y., Miura, I., Wong, P.B., Murphy, R.W., Zeng, X., 2014. The evolution of mitochondrial genomes in modern frogs (Neobatrachia): nonadaptive evolution of mitochondrial genome reorganization. BMC Genomics 15, 691. http://dx.doi.org/10.1186/1471-2164-15-691.

Yong, H.S., Song, S.L., Lim, P.E., Eamsobhana, P., Tan, J., 2016. Complete mitochondrial genome and phylogeny of Microhyla butleri (Amphibia: Anura: Microhylidae). Biochem. Syst. Ecol. 66, 243-253.

Zhang, P., Liang, D., Mao, R.-L., Hillis, D.M., Wake, D.B., Cannatella, D.C., 2013. Efficient sequencing of anuran mtDNAs and a mitogenomic exploration of the phylogeny and evolution of frogs. Mol. Biol. Evol. 30, 1899-1915. http://dx.doi.org/10.1093/molbev/mst091.

Zhou, Y., Zhang, J.-Y., Zheng, R.-Q., Yu, B.-G., Yang, G., 2009. Complete nucleotide sequence and gene organization of the mitochondrial genome of Paa spinosa (Anura: ranoidae). Gene 447, 86-96. http://dx.doi.org/10.1016/j.gene.2009.07.009. 